\title{
BYOD Implementation Factors in Schools: A Case Study in Malaysia
}

\author{
Yusri Hakim bin Yeop ${ }^{1}$, Zulaiha Ali Othman ${ }^{2}$, Siti Norul Huda Sheikh Abdullah ${ }^{3}$, Umi Asma' Mokhtar ${ }^{4}$, Wan Fariza \\ Paizi Fauzi ${ }^{5}$ \\ Center for Cyber Security, Faculty of Information Science and Technology, \\ Universiti Kebangsaan Malaysia, Bangi, Selangor, Malaysia
}

\begin{abstract}
The Bring Your Own Device (BYOD) initiative has been implemented widely in developed countries as a mechanism to prepare the students for the 4th industrial revolution. Success stories of the initiative vary depending on factors pertaining to its implementation. This study aims to identify the key factors to implement BYOD in schools for educational purposes. The research employed a mix-method approach by means of a survey. The data was collected from teachers through questionnaires and and from the school management through interviews. The respondents included 204 teachers from 5 schools in Putrajaya and Dengkil. Principals, senior assistants, ICT teachers and technicians from three schools were interviewed. They represented the school management group. A descriptive statistical analysis is conducted using SPSS statistical software. The research has identified four key factors for the successful implementation of BYOD in Malaysian schools. Two of the factors are related to the Cyber Security Policy at the schools enforcing a secure network infrastructure and safety control requirement in the implementation of BYOD at schools. These security-related factors are important for the schools from the very beginning. They can be further categorized according to the implementation stages: pre-, during and post-adoption; cost allocation, preparation of controls and training to support BYOD's implementation at schools are the corresponding factors to each stage. On the other hand, the other two key factors are related to the schools' readiness - ensuring the successful implementation of BYOD whereby the school management group is willing and prepared to tackle any arising BYOD-related issues in the future.
\end{abstract}

Keywords-Cybersecurity awareness; cybersecurity education; safety; school cybersecurity policy

\section{INTRODUCTION}

The Information and Communication Technology (ICT), particularly the Internet has changed our lifestyle in various ways namely in communication, education, business, and governance. One of the impacts of ICT can be seen through the rapid changes of the education system, from conventional to modern system. The conventional system is believed to be old- fashion that needs more innovations in order to keep up with the technology. It is believed that with the 21 st century technology, schools have more opportunities and ability to shape the education system, and no longer dependent on the poorly funded-educational system or limitation of resources. According to [1], the educational technology is a systematic and organized process of applying modern technology to improve the quality of education, for example, learning and teaching and help with the application of modern educational teaching techniques. The domain of educational technology is apparent where technology is used as a teaching and learning tool and as a tutor. However, the educational technology is still not implemented sufficiently. One of the reasons is due to the lack of school equipment. Hence, many countries have initiated the Bring Your Own Device (BYOD) to school program to overcome the issue, and at the same time, to embrace the technology for promoting a better education system.

\section{BRING YOUR OWN DEVICE}

BYOD is defined as the practice of allowing ones to bring their own personal devices to the workplace for the work purposes [2]. In this study, BYOD is referred to as a concept that allows the students to bring personal devices such as laptops or tablets for better learning interaction and experience [3].

\section{A. The Implementation of BYOD in European Countries}

In European countries, the ownership and type of devices that can be brought to school to facilitate the school to manage the usable devices and applications have been determined in the last five years [4]. Table 1 tabulates findings from the BYOD implementation in nine European countries, covering various factors such as infrastructure, security, application, knowledge, constraints, benefit, and method of use. Each country has its own mechanism on how to implement BYOD in schools, which is also dependent on the country's policy. For example, in Estonia, the focus is more on the application factor as compared to other countries. The applications used are Showbie, Socrative and Padlet, whereas, other countries like Norway, Portugal, United Kingdom, Austria, Finland, and Switzerland do not specify the applications for student's learning. All of the countries acknowledged that the factors i.e infrastructure, security and knowledge are deemed important to be considered when implementing BYOD.

The are several constraints i.e. slow Internet connection, lack of ICT knowledge, device's security, costly devices, limited access, device's specification and data package as well as health and social issues, which need to be addressed if the government wants to continue implementing BYOD to schools. Since students are explosed to the gadgets and technology at the young age, a control mechnisme must be imposed as practised in Finland, Ireland and Switzerland to prevent addiction and negative influences.

We would like to thank the Universiti Kebangsaan Malaysia for financial support through a research grant: DCP-2017-015/4. 
TABLE I. SUMMARY OF BYOD IMPLEMENTATIONS IN THE EUROPEAN COUNTRIES [4]

\begin{tabular}{|c|c|c|c|c|c|c|c|c|c|}
\hline & 1 & 2 & 3 & 4 & 5 & 6 & 7 & 8 & 9 \\
\hline Infrastructure: \\
1. Type of Device; 2. Device Ownership/Financing; 3. Internet Network
\end{tabular}

\begin{tabular}{|l|l|l|l|l|l|l|l|l|l|}
\hline 1.1 Notebook & $/$ & & $/$ & & $/$ & $/$ & $/$ & & $/$ \\
\hline 1.2 Tablet/Ipad & $/$ & $/$ & $/$ & $/$ & $/$ & $/$ & $/$ & $/$ & $/$ \\
\hline 1.3 Smartphone & $/$ & $/$ & $/$ & $/$ & $/$ & $/$ & $/$ & & $/$ \\
\hline 2.1 Parents own the device & $/$ & $/$ & & $/$ & $/$ & $/$ & $/$ & $/$ & $/$ \\
\hline 2.2 School provides to students & $/$ & & & & & $/$ & $/$ & & \\
\hline 2.3 Government subsidized & & & $/$ & & & & & & \\
\hline $\begin{array}{l}\text { 3.1 School/Government provides } \\
\text { the WiFi }\end{array}$ & $/$ & $/$ & & $/$ & & $/$ & $/$ & & \\
\hline 3.2 Access Point (WiFi in class) & & $/$ & $/$ & & & $/$ & $/$ & $/$ & \\
\hline $\begin{array}{l}\text { 3.3 Broadband Network Capacity } \\
\text { up to 100Mbps }\end{array}$ & & $/$ & $/$ & & & $/$ & & & $/$ \\
\hline $\begin{array}{l}\text { 3.4 Improving schools' network } \\
\text { (sponsorship/government) }\end{array}$ & & & & & & $/$ & & & \\
\hline 3.5 Technical Assistant provided & & & & & $/$ & & $/$ & & $/$ \\
\hline $\begin{array}{l}\text { 3.6 External vendor assistance for } \\
\text { technical services }\end{array}$ & $/$ & $/$ & & & & & $/$ & \\
\hline $\begin{array}{l}\text { 3.7 Provides a charging station and } \\
\text { a personal safe }\end{array}$ & & $/$ & & & & $/$ & & \\
\hline \multicolumn{2}{|l|}{ Security } & & & & & \\
\hline
\end{tabular}

\begin{tabular}{|l|l|l|l|l|l|l|l|l|l|}
\hline Firewall usage & & $/$ & & & $/$ & & & & \\
\hline Mobile device management & & & & & & & & & $/$ \\
\hline $\begin{array}{l}\text { Specifications of student personal } \\
\text { devices are determined by the } \\
\text { school }\end{array}$ & & & & & & $/$ & & $/$ & \\
\hline $\begin{array}{l}\text { No specifications for student } \\
\text { personal devices }\end{array}$ & $/$ & $/$ & $/$ & $/$ & $/$ & & $/$ & & $/$ \\
\hline Student's devices inspection Kpplication & & & & & & $/$ & & & \\
\hline \multicolumn{2}{|c|}{ Knowledge } & & & & & & \\
\hline Office 365 (Cloud) & $/$ & & & & & & & & \\
\hline Showbie (school paperless apps) & $/$ & & & & & & \\
\hline Socrative (quiz and training apps) & $/$ & & & & & & & & \\
\hline Padlet (digital whiteboard) & $/$ & & & & & & & & \\
\hline Edmodo (school paperless apps) & & & & & & & & $/$ & \\
\hline $\begin{array}{l}\text { Teachers are qualified and } \\
\text { technology savvy }\end{array}$ & $/$ & $/$ & $/$ & & $/$ & $/$ & $/$ & & \\
\hline $\begin{array}{l}\text { Trained students can help other } \\
\text { students in device problem }\end{array}$ & & & $/$ & & $/$ & & $/$ & $/$ & $/$ \\
\hline $\begin{array}{l}\text { Provides ICT training and Internet } \\
\text { safety for teachers }\end{array}$ & $/$ & & $/$ & $/$ & $/$ & & $/$ & $/$ & $/$ \\
\hline $\begin{array}{l}\text { ICT use of pedagogical exercise to } \\
\text { teachers }\end{array}$ & & $/$ & & $/$ & & $/$ & $/$ & $/$ \\
\hline
\end{tabular}
teachers

\section{Constraints}

\begin{tabular}{|l|l|l|l|l|l|l|l|l|l|}
\hline Slow Internet connection & $/$ & & & $/$ & & & & $/$ & \\
\hline $\begin{array}{l}\text { Lack of ICT knowledge among } \\
\text { teachers }\end{array}$ & & & & $/$ & & & & & \\
\hline $\begin{array}{l}\text { Effect of the networks filter (i.e. } \\
\begin{array}{l}\text { FB, YouTube, and online games) } \\
\text { causing limited access to the apps }\end{array}\end{array}$ & & & & $/$ & & & & & \\
\hline $\begin{array}{l}\text { Use private data package due to } \\
\text { poor school WiFi }\end{array}$ & $/$ & & & & & & & & \\
\hline $\begin{array}{l}\text { Parental worries about device } \\
\text { security }\end{array}$ & $/$ & & & & & & & & \\
\hline $\begin{array}{l}\text { Students device is damaged or } \\
\text { forgot to carry the device }\end{array}$ & & $/$ & & & & & & & \\
\hline $\begin{array}{l}\text { Low specs devices and interferes } \\
\text { with learning Health problem }\end{array}$ & & & & & & & & & $/$ \\
\hline Expensive device & $/$ & & & & & & & & \\
\hline $\begin{array}{l}\text { Government charges Internet but it } \\
\text { is not enough to buy the right }\end{array}$ & $/$ & & & & & & & & \\
\hline
\end{tabular}

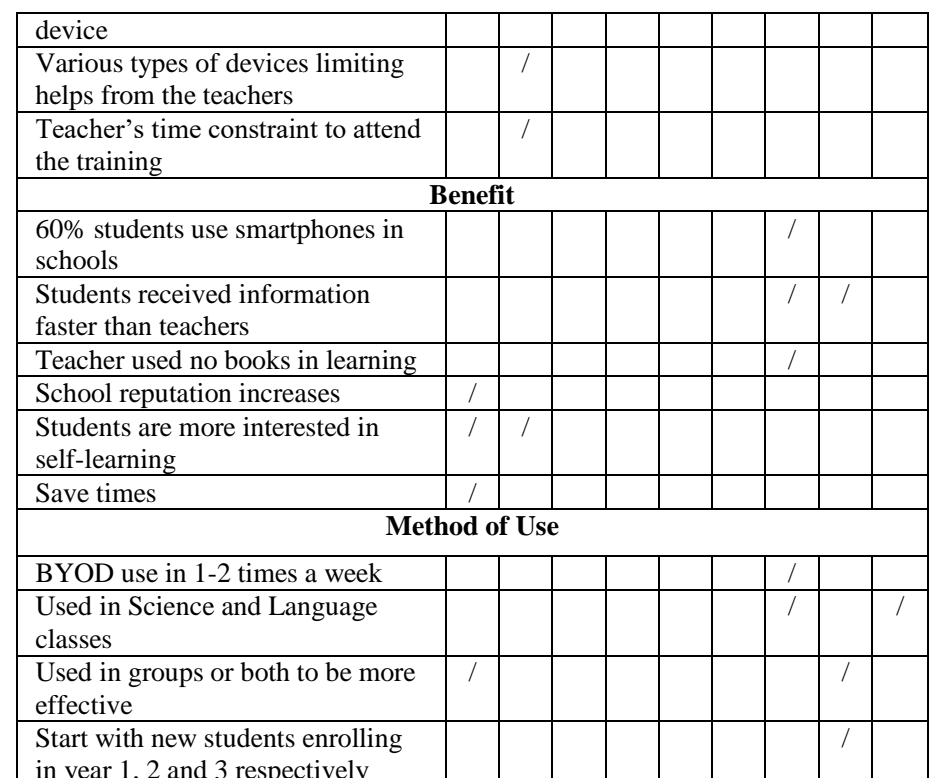

in year 1,2 and 3 respectively

1-Estonia, 2-Dublin, 3-Norway, 4-Portugal, 5-United Kingdom, 6-Austria, 7-Finland,8-Ireland, 9

Switzerland

\section{B. BYOD in Malaysia}

In Malaysia, the Ministry of Education (MOE) has realized the importance of the Internet and spent over 6 billion Ringgit Malaysia for the development of ICT in education, such as Smart School [5]. The basis of learning in schools is writing, reading and counting $(3 \mathrm{M})$, but it is no longer sufficient for the 21 st century education, which requires the 21 st century skills such as critical thinking and problem-solving skills. According to [6][7], students need to be equipped with the $21^{\text {st }}$ century skills to ensure their competitiveness in the globalization era. It comprised of four domains namely digital age literacy, inventive thinking, effective communication and high productivity.

Hence, MOE had transformed the existing national education curriculum to develop students who are balanced, resilient, curious, principled, informed, caring, patriotic, creative, able to think critically, communicate and work effectively in a team [8]. MOE wanted to ensure the students are capable to compete at the international level. On January 13, 2018, Malaysian education ministers have announced that 2000 classes in selected schools will be equipped with $21^{\text {st }}$ Century Learning (PAK-21) classes [9], especially using project-based approaches [8]. Technology is an important component of the PAK-21 classes and this posed a challenge for MOE because of the high cost needed to provide adequate, up-to-date and secure computer labs for the schools. In addition, it is evident that the existing school network (1BestariNet) needs to be upgraded to support this effort.

MOE has recommended BYOD for Teaching and Facilitation (T\&F) and for other activities supporting the implementation of the curriculum and co-curriculum. On March 29, 2018, MOE issued a memorandum outlining the BYOD policy for schools and guidelines for the implementation of BYOD at schools [10]. The BYOD policy listed the permitted types of devices which include laptops, tablets, audio devices or any other devices except for smart phones. These devices may be owned by parents or guardians. 
Devices can also be contributed by the Parents and Teachers Association (PTA), schools, organizations or individuals. The BYOD policy also described several device control and security measures such as device registration, periodic checking, reporting in case of loss, secure Internet and Wi-Fi access, safe storage and charging stations in the classrooms.

Various issues need to be considered before implementing BYOD in Malaysian education system specifically teachers' knowledge [11], social problems [12], infrastructure [13], security [13], health issues [14], financial capability [14], etc. A teacher's technical knowledge on ICT and safety-related knowledge when engaging in the cyberspace is important to help the school to successfully implement BYOD, as stated by [9] that teachers are still having problem in dealing with new technology. If teachers are technically skillful, then they can assist the schools to improve the quality of learning in Malaysia with the implementation of BYOD.

This study investigated the level of knowledge and skills of teachers in terms of ICT, cyber security and Malaysian cyber laws as well as the existing school infrastructure. This study also investigated the level of readiness to implement the BYOD and categorized the factors based on the three categories which will be further discussed in this paper.

\section{Teaching and Facilitation}

Student and teacher have a mixed learning styles and teaching styles preferences respectively, which means it is important for teachers to adopt appropriate instructional strategies [15]. This is due to technology advancements which has changed the traditional learning and teaching styles causing diversity methods in education system. One of the examples to accommodate the changes is through selfregulated learners by embracing the Education 3.0 that using technology as a tool in teaching and learning [16]. The Education 3.0 is more e-learning driven that offers open and flexible learning activities in order to create room for student creativity and social networking outside traditional boundaries. Hence, the Teaching and Facilitation approach is suitable in the $21^{\text {st }}$ Century Learning.

\section{METHODOLOGY}

This research employed a mixed method approach [17-19] that consists of three phases.

Phase 1 is a literature study and statement of research problems. Phase 2 is the phase of studying the possible factors affecting the implementation of BYOD at schools by referring to the key elements in [5]. The data are collected through three techniques: literature review, a closed forum on the cyber issues in Malaysia and interviews of personnel from involved agencies across the ICT and education government sectors. The questionnaires are distributed to teachers in schools around Putrajaya and Dengkil. While interviews were conducted with school administrators, ICT teachers and school technical staff from schools in Putrajaya and Dengkil to further strengthen the findings from the questionnaires.

Lastly, Phase 3 is data analysis using statistical analysis to find put the factors that influence and the level of readiness to implement BYOD.

\section{A. Questionnaire and Interview}

The questionnaire was divided into five components namely (A) General profile of the respondent, (B) School infrastructure availability and readiness of school implement BYOD in their school, (C) Preparation of security controls safely, (D) Level of teacher knowledge and readiness applying BYOD and (E) Teacher's opinion(s) on health issues if BYOD is implemented. All of the questions use the Likert scale method with measurements of 1 to 5 where the answer scale used is 1 = Strongly Disagree, 2 = Disagree, $3=$ Simple Agree, 4 = Agree, $5=$ Strongly Agree .

A total of 4 interview sessions were conducted in a period of one month in 3 schools. Each interview session was between one to two hours.

\section{B. Closed Forum}

A closed-session discussion entitled "Cybersecurity: Towards a Secure and Sustainable Cyber Use" was held at UKM with invited participants from the government sectors i.e. Royal Malaysia Police, Ministry of Women, Family and Community Development, Ministry of Education, Ministry of Communications and Multimedia Commission, Law faculty of Universiti Kebangsaan Malaysia and the National Occupational Safety and Health Institute. The forum discussed the government's efforts to direct/foster Malaysians towards a safe and healthy/beneficial cyber culture. Each department's or agency's representative to share his/her views regarding the proposed title for 40 minutes followed by a 10 -minute session for questions and answers.

\section{Respondents, Sampling, Distribution and Fieldwork}

Within a two-week time frame, a total of 300 sets of questionnaires were distributed to five government primary and secondary schools in Putrajaya and Dengkil. A total of 222 sets were returned of which 18 sets were rejected because the forms were incomplete and contained dubious answers. Hence, only 204 sets, which is $68 \%$ of the total set distributed, can be analyzed using SPSS software.

\section{TABLE II. INFRASTRUCTURE}

\begin{tabular}{|l|l|l|l|l|l|}
\hline No & Item & L & F & CSM & BTP \\
\hline 1 & $\begin{array}{l}\text { Expansion of school internet access and } \\
\text { access control }\end{array}$ & $/$ & $/$ & & / \\
\hline 2 & Provision of Locker to save device & & $/$ & & \\
\hline 3 & Technical requirements & $/$ & & & $/$ \\
\hline 4 & Class changes to suit PAK-21 & $/$ & & & \\
\hline 5 & 1 device / high school student & $/$ & & & \\
\hline 6 & $\begin{array}{l}\text { Ease of charging in class and preparation } \\
\text { of power sockets }\end{array}$ & $/$ & & & \\
\hline 7 & BYOD Model Type & $/$ & $/$ & & \\
\hline 8 & Wi-Fi capability & $/$ & & & \\
\hline 9 & Use of MDM or Content Filtering & $/$ & & & $/$ \\
\hline 10 & Ability of broadband available & $/$ & & & \\
\hline 11 & Equipped with anti-virus applications & $/$ & & & \\
\hline & L-Literature, F-Forum, CSM-Cyber Security Malaysia, BTP - Education Technology Division \\
\hline
\end{tabular}




\section{DATA ANALYSiS}

This section discusses the findings of the questionnaires and interviews on the key factors of BYOD Implementation in the local government schools to establish a school preparation model for the implementation of BYOD. This section is divided by two parts: (A) Findings from the Questionnaires and (B) Findings from the Interview.

\section{A. First Part: Findings from the Questionnaire}

1) Infrastructure:-There are four factors namely Infrastructure, Health, Safety and Knowledge to implement BYOD in schools. Each factor consists of several elements. In Table II, all the selected elements that contributed to the Infrastructure factor are listed. It was generally agreed that 'expansion of school internet access and access control' is one of the important elements. The technical requirements, lockers as a place to keep the devices, 1 device 1 student, charging station, WiFi, and more are also important to implement the BYOD.

The readiness level is identified based on the mean value, which is interpreted as follows:

- 4.00 - 5.00: High

- 3.00 - 3.99: Medium

- 2.00-2.99: Low

- $1.00-1.99$ : Very low

- $0.00-0.90$ : Not available

Table III shows the analysis result of readiness of the school facilities of the school to implement BYOD. The needs of ICT technicians are high. Also, other criteria such as internet connection, power sockets, tables, chairs, safety locker are still insufficient. Respondents agreed that the school should provide devices/mechanism for content filtering or restrictions on internet materials that are not suitable for students in the school's Wi-Fi network. Hence, the level of respondent's readiness on the content filtering is at a medium level. Overall, it can be concluded that school infrastructure is not yet ready for implementing BYOD.

TABLE III. READINESS OF SCHOOL FACILITIES FOR BYOD

\begin{tabular}{|l|l|l|l|}
\hline Topic & Mean & $\begin{array}{l}\text { Std. } \\
\text { Deviation }\end{array}$ & $\begin{array}{l}\text { Readiness } \\
\text { Level }\end{array}$ \\
\hline Internet Connection & 2.76 & 1.111 & Low \\
\hline Wi-Fi & 2.55 & 1.28 & Low \\
\hline Content Filtering & 3.11 & 1.2 & Medium \\
\hline Power socket in Classroom & 2.44 & 1.167 & Low \\
\hline Tables and Chairs & 2.83 & 1.252 & Low \\
\hline Safety Locker & 2.81 & 1.402 & Low \\
\hline The need of ICT Technician & 4.5 & 0.833 & High \\
\hline
\end{tabular}

2) Health:- Table IV indicates that Health factor is one of the factors to be considered when implementing the BYOD. The common health issues include eye sight problems either far/near sighted, Internet addiction, loss of focus due to lack of sleep; and the need to have a control mechanisme at home to prevent problems in school.

TABLE IV. HEALTH

\begin{tabular}{|l|l|l|l|l|l|}
\hline No & Item & L & F & CSM & BTP \\
\hline 1 & $\begin{array}{l}\text { The risk of farsightedness, the time to } \\
\text { look over the screen }\end{array}$ & $/$ & & & \\
\hline 2 & Internet addiction, attitude change & $/$ & & $/$ & \\
\hline 3 & $\begin{array}{l}\text { Failing to complete schoolwork, lost } \\
\text { learning focus }\end{array}$ & $/$ & & & \\
\hline 4 & $\begin{array}{l}\text { Control the use of internet at home to } \\
\text { avoid problems in school }\end{array}$ & & & $/$ & \\
\hline
\end{tabular}

L-Literature, F-Forum, CSM-Cyber Security Malaysia, BTP - Education Technology Division

Table $\mathrm{V}$ shows the impact of implementing BYOD on students' health and attitude. The level of risk pertaining to the health issues i.e. gadget addiction and schoolwork disruption are high. Since the students are young users, the monitoring and controlling mechanism need to be imposed to avoid severe repercussions.

TABLE V. HEALTH's Risks AmONG StUdENTS

\begin{tabular}{|l|l|l|l|}
\hline Topic & Mean & $\begin{array}{l}\text { Std. } \\
\text { Deviation }\end{array}$ & Level \\
\hline $\begin{array}{l}\text { Blindness due to excessive use of } \\
\text { gadgets }\end{array}$ & 3.73 & 1.098 & Medium \\
\hline $\begin{array}{l}\text { Tired, sleepy or lost focus in the } \\
\text { classroom }\end{array}$ & 3.78 & 0.978 & Medium \\
\hline Failed to complete the schoolwork & 4.03 & 0.898 & High \\
\hline $\begin{array}{l}\text { Different attitude when at home and } \\
\text { at school due to internet addiction. }\end{array}$ & 3.82 & 0.892 & Medium \\
\hline Uncontrolled gadgets and internet & 4.08 & 0.78 & High \\
\hline
\end{tabular}

Respondents agreed that the uncontrolled use of gadgets affected students' performance and was the cause of students failing to complete their homework. Internet addiction or excessive use of gadgets can change student attitudes. Respondents also agreed that their students behaved differently at home and at school. Students were either quiet in school but too active at home or vice versa. Internet addiction was identified to be the cause of the change of attitude and could disrupt the student's social relationships with friends or family.

3) Safety:- The elements related to safety factor are listed in the Table VI. The respondents agreed that student safety is important in both aspects: the data and devices. 
TABLE VI. SAFETY

\begin{tabular}{|c|l|c|c|c|c|}
\hline No & \multicolumn{1}{|c|}{ Item } & L & F & CSM & BTP \\
\hline 1 & $\begin{array}{l}\text { Comply to National Security Policy } \\
\text { (RAKKSSA) for safety reason } \\
\text { including environment, technology, } \\
\text { human, threats, and audit }\end{array}$ & $/$ & & & \\
\hline 2 & $\begin{array}{l}\text { Understand the related laws i.e. } \\
\text { Cyber law and cyber threats }\end{array}$ & $/$ & & & $/$ \\
\hline 3 & $\begin{array}{l}\text { Student safety: personal data and } \\
\text { devices }\end{array}$ & & $/$ & $/$ & / \\
\hline 4 & Introduce safety procedures & & $/$ & & \\
\hline
\end{tabular}

Table VII shows the results concerning safety control at school before implementing BYOD. The table shows that all four elements under the safety factor are at medium and high levels. Respondents affirmed that the school should determine the specifications and types of devices that are allowed and these devices have to be registered and reviewed by the schools before they can be allowed to connect to the school's network. The needs for device registration, anti-virus and good school's WiFi network are high to enable the school's management to provide a safe and secure environment and to control student's online activities and use the devices for educational purposes only.

TABLE VII. THE NEED OF SAFETy CONTROL

\begin{tabular}{|l|l|l|l|}
\hline Question & Mean & $\begin{array}{l}\text { Std. } \\
\text { Deviation }\end{array}$ & $\begin{array}{l}\text { Needs } \\
\text { level }\end{array}$ \\
\hline Device spec. determined by school & 3.84 & 1.094 & Medium \\
\hline Device registration & 4.06 & 1.126 & High \\
\hline Guarded with Anti-virus & 4.32 & 0.771 & High \\
\hline School Wi-Fi only & 4.21 & 1.122 & High \\
\hline
\end{tabular}

4) Knowledge:- Table VIII indicates that knowledge of cyber law and cyber threats are important and syllabus must be created for the cyber space curriculum.

TABLE VIII. KNOWLEDGE

\begin{tabular}{|l|l|l|l|l|l|}
\hline No & Item & L & F & CSM & BTP \\
\hline 1 & $\begin{array}{l}\text { Knowledge of cyber law and cyber } \\
\text { threats }\end{array}$ & $/$ & & $/$ & \\
\hline 2 & $\begin{array}{l}\text { Creating a syllabus for Cyberspace } \\
\text { curriculum for high school students }\end{array}$ & $/$ & & & \\
\hline
\end{tabular}

L-Literature, F-Forum, CSM-Cyber Security Malaysia, BTP - Education Technology Division

Table IX shows the result of teachers' knowledge on the Government Initiatives on Cyber Security and Cyber Law. The teacher's level of awareness on cyber programs, skills in ICT, and skills in cyber security are still at the medium level. Nonetheless, the teachers realized that materials in the Internet can be used as a learning tool.
TABLE IX. LEVEL OF TEACHER’s KNOWLEDGE

\begin{tabular}{|l|l|l|l|}
\hline Question & Mean & $\begin{array}{l}\text { Std. } \\
\text { Deviation }\end{array}$ & Level \\
\hline $\begin{array}{l}\text { Knows about awareness } \\
\text { programs related to cybercrime } \\
\text { and the cyber ethics }\end{array}$ & 3.89 & 0.724 & Medium \\
\hline $\begin{array}{l}\text { Materials in the Internet can be } \\
\text { used as a learning tool }\end{array}$ & 4.42 & 0.665 & High \\
\hline $\begin{array}{l}\text { Skilled teacher who can handles } \\
\text { laptops, tablets or iPad }\end{array}$ & 3.84 & 0.961 & Medium \\
\hline $\begin{array}{l}\text { Skilled teacher in cyber security } \\
\text { knowledge and its threats }\end{array}$ & 3.59 & 0.991 & Medium \\
\hline
\end{tabular}

\section{B. Second Part: Findings from the Interview}

Three out of the seven schools that have been approached, agreed to be interviewed: School A, School B and School C. Additional interviews were conducted at the Education Technology Division, MOE to gather more information.

Based on the analysis on the feedback from school administrators on the school's readiness to implement BYOD for Teaching and Facilitation, various issues such as device security, the increased in the teacher workload, inferiority complex among students, parental financial abilities and social media contagion are factors that can undermine BYOD's implementation. All these issues needed further investigation. In terms of infrastructure and facilities, the number of power sockets in the classrooms were inadequate, some of which were not well-maintained. Overall, it can be concluded that the readiness of infrastructure at these schools are still at a low level.

The school management group were also concerned about the safekeeping of personal devices. Students did not have their own lockers. Other issues highlighted include the current tables and chairs were not suitable for personal device use because of the non-ergonomic designs that will cause neck and back pain due to incorrect sitting posture and inappropriate when using the device; the capability of existing Internet is insufficient; there is not enough ICT assistants to assist schools in technical matters - some schools do not have technical specialists and ICT teachers have to take over the task of maintaining the computer laboratory and repairing damaged computers which impacted the effectiveness of the students' learning experiences.

\section{RESULTS AND DisCUSSION}

This research has identified four important factors needed to be addressed to achieve the aspirations of MOE's strategic plan in providing virtual education. These four factors are the availability of infrastructure, knowledge of health impacts, safety control requirements and skill level and teacher knowledge. Figure 1 shows the current status of the four factor that the schools need to improve to reach the readiness level to implement BYOD in schools. 


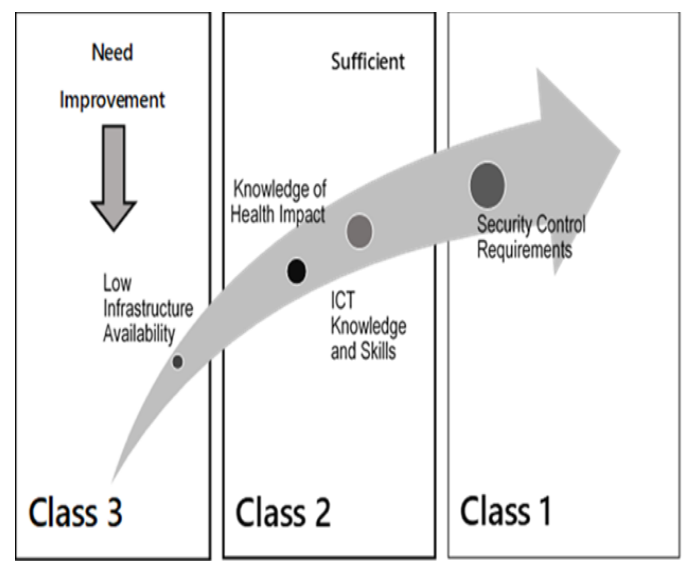

Fig. 1. Readiness Category.
Three Readiness Categories have been identified; essential, sufficient and need improvement. These readiness levels were extracted from the analysis of the respondents' responses. The category of readiness is presented to indicate which factors need more enhancement in order to implement BYOD. The categories are prioritized in ascending order from 1 to 3 , which 1 as critically needed (essential), 2 as currently adequate/sufficient and 3 as need improvement.

In Class 1: Essential, majority of the respondents were concerned on the need to create security controls to protect pupils and teachers from cybercrime. Documents such as school's cyber security policy should be designed, produced, enforced and complied with to control the use of personal devices of teachers and pupils. In addition, some forms of control should also be applied to address thefts, damages and health problems.

TABLE X. Proposed LIST OF ELEMENTS FOR EACH FACTOR

\begin{tabular}{|c|c|}
\hline \multicolumn{2}{|c|}{ Factor 1: Availability of the infrastructure } \\
\hline A & An internet network that can accommodate all school users including students in the same time. \\
\hline $\mathrm{B}$ & The stress test for the network is required \\
\hline $\mathrm{C}$ & The extensive Wi-Fi network coverage also includes every class, garden and school canteen. \\
\hline $\mathrm{D}$ & Stress test against $\mathrm{Wi}-\mathrm{Fi}$ access point (access point) \\
\hline $\mathrm{E}$ & Preparation and maintenance \\
\hline $\mathrm{F}$ & Content filtering (content filtering) for monitoring internet access \\
\hline G & Provide adequate power sockets for area charging devices in the classroom \\
\hline $\mathrm{H}$ & Preparation of a locked-up device for storage of personal mobile devices \\
\hline I & Provision of table chairs in the classroom that suit the use of personal mobile devices \\
\hline $\mathrm{J}$ & Provision of backup devices for the use of students experiencing problems on their \\
\hline \multicolumn{2}{|c|}{ Factor 2: Health effects } \\
\hline A & $\begin{array}{l}\text { Screen time-consuming control. } 20 \text { minutes exposed to the screen requires } 20 \text { seconds break and look at objects that are positioned } 20 \text { meters from the } \\
\text { eye }(20-20-20)\end{array}$ \\
\hline $\mathrm{B}$ & Train pupils proper body posture while using mobile devices \\
\hline $\mathrm{C}$ & Train pupils to assess the bad information or images viewed on the internet \\
\hline $\mathrm{D}$ & Conduct training sessions for parents and students in controlling the use of gadget or home internet \\
\hline \multicolumn{2}{|c|}{ Factor 3: Security control requirements } \\
\hline A & The permitted mobile device specification is determined by the school \\
\hline $\mathrm{B}$ & Registration must be made on all student mobile devices before they can be used within the school. \\
\hline $\mathrm{C}$ & The carry-in device is already equipped with anti-virus \\
\hline $\mathrm{D}$ & Perform random investigation on devices to ensure they are safe from any intrusion. \\
\hline $\mathrm{E}$ & Procedure to report on theft, loss and abuse. \\
\hline $\mathrm{F}$ & Devices are only allowed access to school internet access only for monitoring \\
\hline $\mathrm{G}$ & Create safety rules for mobile devices for teachers and students \\
\hline $\mathrm{H}$ & Establishing safe internet usage ethics guidelines at school for students, teachers and administrators \\
\hline \multicolumn{2}{|c|}{ Factor 4: Knowledge and skill } \\
\hline A & Basic training on network operation and specific software \\
\hline $\mathrm{B}$ & Training cyber security skills and threats to teachers and students \\
\hline $\mathrm{C}$ & Duties and responsibilities of technical interpreters \\
\hline $\mathrm{D}$ & Exposure to teachers and students towards cyber security and internet awareness programs organized by the gover \\
\hline
\end{tabular}


In Class 2: Sufficient refers to teachers having good skills in terms of knowledge of ICT's handling, health effects, internet usage and social media, cybercrimes and cyber awareness campaigns that have been conducted by the government as well as private organizations. The analysis also showed that the school administrators support the use of personal devices to schools for Teaching and Facilitation.

In Class 3: Need Improvement category, the infrastructures and supplies are limited. Key infrastructures such as internet network and Wi-Fi capabilities provided by the government in schools are insufficient so schools have to subscribe to other internet service providers to accommodate the teachers' needs. Only schools in Putrajaya have facilities such as power sockets in the classroom and equipment storage lockers but many are not well-ventilated and most of them are damaged.

Besides the Readiness's Category, this study also proposed four factors which based on the findings. The factors are the basis for the successful implementation of BYOD as shown in Table X.

All of the factors served as a basis that need to be considered before implement the BYOD. For example, the knowledge refers to both practical and theoretical. Teachers who are technology savvy have more skills and knowledge to teach their students using learning applications effectively. Despite using the YouTube for entertainment only, the teachers can guide the students to channel their creativity and learn interactively by watching the videos. Some of the lessons need to be demonstrated rather than explain narratively, which can be fully utilized via the YouTube channel. It is also noted that the knowledgeable teachers have better understanding to use the BYOD appropriately and effectively. A conducive infrastructure would influence to the implementation and can avoid technical disruptions. Health and security factors cannot be neglected particularly when involving young students and cyber environments. Both are crucial due to many social impacts occurring nowadays. Therefore, all the proposed factors have considered the technical, social and knowledge aspects to provide a foundation for better implementation as well as student's wellbeing.

\section{ACKNOWLEDGMENT}

We would like to thank Universiti Kebangsaan Malaysia for financial support through grant DCP-2017-015/4.

\section{REFERENCES}

[1] Stošić, Lazar. 2015. The Importance of Educational Technology in Teaching. International Journal of Cognitive Research in Science, Engineering and Education. 3(1): 111-114.
[2] Oxford 2010. Oxford reference. Retrieved from http://www.oxfordreference.com

[3] Kementerian Pendidikan Malaysia. 2011. Pelan strategik interim 20112020. Ministry of Education. Retrieved from www.moe.gov.my/bppdp.

[4] Attewell, J. 2015. BYOD - A Guide for school leaders. Designing the Future Classroom (3): 1-64. European Schoolnet.

[5] Kementerian Pendidikan Malaysia. 2013. Pelan Pembangunan Pendidikan Malaysia 2013-2015. Kementerian Pendidikan Malaysia, hlm. Vol. 1. doi:10.1016/j.tate.2010.08.007.

[6] Punia Turiman, Jizah Omar, Adzliana Mohd Daud, and Kamisah Osman. 2012. Fostering the $21^{\text {st }}$ Century Skills through Scientific Literacy and Science Process Skills. Procedia-Social and Behavioral Science. 59(2012): 110-116.

[7] Radha M K Nambiar, Noorizah Mohd Nor, Kemboja Ismail, and Shahirah Adam. 2017. New Learning Spaces and Transformations in Teacher Pedagogy and Student Learning Behavior in the Language Learning Classroom. 3L: The Southeast Asian Journal of English Language Studies. 23(4): 29-40.

[8] Romarzila Omar, Zanaton H. Iksan, Sharifah Nor Puteh, 2018, A Comprehensive 21st Century Child Development through Project Based Learning 1, Journal of Adv Research in Dynamical \& Control Systems, 10 (06-Special Issue): 1636-1642 1636.

[9] Hayati Ismail. 2018. Pembelajaran abad ke-21: Harapan, realiti dan cabaran. Utusan Online. Retrieved from http://www.utusan. com.my/rencana/utama/pembelajaran-abad-ke-21-harapan-realiti-dancabaran-1.590819.

[10] Kementerian Pendidikan Malaysia. 2018. GP DASAR MURID MEMBAWA PERANTI.pdf. Kementerian Pendidikan Malaysia.

[11] Pramela Krish and Noraza Ahmad Zabidi , 2007, TEACHERS AND THE NEW ICT CHALLENGES, School of Language Studies and Linguistics, journal e-bangi. 2(2) : Januari - Disember 2007.

[12] Fauziah Ahmad, Chang Peng Kee, Normah Mustaffa, Faridah Ibrahim, Wan Amizah Wan Mahmud and Dafrizal. 2012. Information Propagation and the Forces of Social Media in Malaysia, Asian Social Science Journal. 8(5):71-76.

[13] Khosraw Salamzada, Zarina Shukur and Marini Abu Bakar. 2014. A framework for cyber security strategy for developing country, AseanJapan Workshop on Information Science and Technology 2014, FTSM, UKM.

[14] Dicky Wiwittan Toto Ngadiman, Daily Tayok, Salmy Edawaty Yacoob, and Hairunnizam Wahid. 2018. Social Relationship B40 against Purchasing Behaviour nonbasic Needs using Loans and Intention to Increase debt, International Journal of Academic and Research in Business and Social Sciences, 8(7): 1102 - 1117.

[15] Lee Mei Ph'ng, Thang Siew Ming, and Radha M.K.Nambiar. 2015. Matching Teaching Styles and Learning Styles: What Happens in the Case of a Mismatch? Journal of Social Sciences and Humanities. Special Issue (1):066-076.

[16] Riza Atiq Abdullah O.K Rahmat and Kamisah Osman. 2012. From Traditional to Self-Regulated Learners: UKM Journey towards Education 3.0. Procedia-Social and Behavioral Science. 59 (2012): 2-8.

[17] Board, T. (n.d.). Engaged and informed school leaders drive transformation in Ireland 33-35.

[18] Creswell, J. W. \& Zhang, W. 2009. The Application of Mixed Methods Designs to Trauma Research. 22(6): 612-621.

[19] Robert V Krejcie; D Morgan. 1970. Determining Sample Size For Research Activities. $607-610$. 